\title{
THE SAPOTACEAE OF INDONESIA AND THE POTENTIAL ROLE OF BOTANIC GARDENS IN THEIR CONSERVATION
}

\author{
Prima W.K. Hutabarat ${ }^{1} \&$ Peter Wilkie ${ }^{2}$
}

\begin{abstract}
Indonesia holds a large percentage of Malesian Sapotaceae taxa with an estimated 15 genera and 158 species. Bogor Botanic Gardens currently hold 12 genera and 41 species of which 29 are native to Indonesia. This represents just under $20 \%$ of Sapotaceae species currently recorded from Indonesia. The utility of these collections is dependent on the type of data associated with them and on the quality of identification of the material. Of the 29 native species only three have had a global threat assessment made and, of these, one, Madhuca boerlageana (Burck) Baehni, is considered Critically Endangered. The regional botanic gardens initiative of the Indonesian government is establishing botanic gardens in each of the 47 ecoregions of Indonesia. This new initiative is potentially very important for in situ and ex situ conservation of the Indonesian flora. So far it has brought into cultivation 39 threatened species, however none of these are Sapotaceae. The lack of global IUCN threat data is a major impediment to the prioritisation of collection, cultivation and conservation of Sapotaceae species.
\end{abstract}

\section{INTRODUCTION}

Sapotaceae comprises five tribes, 54 genera and approximately 1,250 species that are mainly found in sub-tropical and tropical areas of the world (Pennington, 1991; Govaerts et al., 2001). Many of them form significant components of the lowland wet forest in America, Africa, Asia and the Pacific Islands. In the Malesian region there are an estimated 15 genera and 300 species of Sapotaceae. They are found in primary forest to 1,700 m altitude and are common in freshwater swamp forest but not mangrove swamps or very exposed peaks ( $\mathrm{Ng}, 1972)$. Wilkie (2011) extended their occurrence from beach forest to mossy montane forest at over $4,000 \mathrm{~m}$. Indonesia holds a large percentage of the Malesian taxa with an estimated 15 genera and 158 species.

Sapotaceae is one of the main families of large trees in Indonesia (with Burseraceae, Dipterocarpaceae and Leguminosae), reaching the top of the canopy and sometimes becoming emergents. They have a high value economically and ecologically (Ng, 1972; Pennington, 1991; Wilkie, 2011). Many species from the genera Madhuca Buch.-Ham., Palaquium Blanco (nyatoh, bitis, jangkar) and Manilkara Adans. (sawo, sawah, duyok-duyok) are lightweight to medium-heavy hardwoods and are used for construction, house building and furniture production, and as such they are categorised

1. Prima Hutabarat is a Researcher at the Center for Plant Conservation Botanic Garden, Indonesian Institute of Sciences. Address: J1. Ir. H. Juanda No. 13 Bogor, Jawa Barat, Indonesia.

Email: hutabaratpwk@gmail.com,prim003@lipi.go.id

2. Peter Wilkie is a Senior Researcher at the Royal Botanic Garden Edinburgh.

Address: 20A Inverleith Row, Edinburgh, EH3 5LR, UK.

Email: p.wilkie@rbge.org.uk 
as major commercial timbers (Soerianegara \& Lemmens, 1994). Other genera such as Burckella Pierre, Diploknema Pierre, Mimusops L. and Chrysophyllum L. also have potential as timber (Lemmens et al., 1995; Sosef et al., 1998). The coagulated latex from the bark or leaves of Palaquium gutta (Hook.) Baill., Madhuca motleyana (de Vriese) J.F.Macbr. and Payena leerii (Teijsm. \& Binn.) Kurz is often termed guttapercha (Boer \& Ella, 2001). In the forest, the fruit of Sapotaceae is often a favoured food source for climbing mammals, bats and birds and these animals help disperse the seeds $(\mathrm{Ng}, 1972)$.

Indonesia, as a megadiverse country, is home to 30,000-40,000 angiosperms (15\% of the total flora of the world), has 40-50\% endemism and 47 different ecosystem types (Wikramanayake et al., 2002; Olson et al., 2001; Kartawinata, 2013; Widjaja et al., 2014). Biodiversity loss in Indonesia is mainly caused by land use and habitat alteration, invasive alien species, natural resources exploitation without planning, environmental pollution and climate change (Widjaja et al., 2014). Miettinen et al. (2011) highlights that deforestation has continued to take place at a higher rate in SE Asia since 2000 with overall forest cover declining $1 \%$ every year. This underlines the importance of Indonesia and the Malesian region as a global conservation priority.

In 1998 Indonesian conservation policy was developed to formalise in situ conservation areas in Indonesia, and in 1999 further policies were incorporated into law to protect native and rare species. To date about $49 \%$ of the total 131 million ha of Indonesian forest has been protected as in situ conservation areas such as national parks, nature reserves and protected forests (Widjaja et al., 2014). In 2011 botanic garden policies were updated to strengthen regional botanic garden programmes and this saw the introduction of regional botanical gardens across Indonesia. This recognised the important role that botanic gardens can play in plant research and conservation (Rakow \& Lee, 2011).

An important source of information that can be used to help prioritise conservation efforts is the International Union for Conservation of Nature (IUCN) Red List of Threatened Species. However, to date only 333 species of Sapotaceae have been globally assessed by IUCN (IUCN, 2001) and only 27 (9\%) cover species from the Malesian region. Moreover, most of these global conservation assessments need to be updated since they were made using the outdated IUCN Categories and Criteria version 2.3 from 1994, not the current version 3.1 (IUCN, 2001).

New and updated assessments of Sapotaceae are needed to deliver global and national objectives and to help drive national conservation activities, particularly in the Malesian region where most of the species have never been assessed. As Indonesia has high diversity and endemism of Sapotaceae and administratively covers much of the Malesian region, it has a core role to play in delivering conservation assessments and conservation actions in the region.

This paper, for the first time, presents an inventory of Sapotaceae held in Indonesia's botanic gardens together with an assessment of their condition and current knowledge of their threat status. How this information can be used to help identify collecting priorities 
and direct in situ and ex situ conservation activities is discussed as are the data gaps regarding threat status.

Indonesia has four national botanic gardens, two lowland gardens (below $300 \mathrm{~m}$ asl) - Bogor Botanic Gardens in West Java and Purwodadi Botanic Garden in East Java - and two montane gardens (between 1,200 and 1,400 m asl) - Cibodas Botanic Garden in West Java and Bali Botanic Garden on the island of Bali. All fall under the auspices of the Indonesian Institute of Sciences (LIPI).

In this paper the term specimen refers to an individual tree or shrub; the term accession refers to all material of a single taxon from a single source that was collected at the same time and of a single propagule type (this can refer to more than one specimen).

\section{BOGOR BOTANIC GARDENS}

Bogor Botanic Gardens (Kebun Raya Bogor) was established in 1817 and is the oldest and most important botanic garden in Indonesia. Since its establishment 251 tree and shrub specimens of Sapotaceae have been planted. Of these 44 are recorded as having died, leaving 207 currently still growing. Of these specimens $57 \%$ have been determined to species, $35 \%$ to genus and $8 \%$ to family. In total the garden holds 12 genera and 41 species of Sapotaceae. At present two accessions of Burckella, one of Madhuca, 18 of Palaquium, four of Pouteria and six indeterminate plants are awaiting expert identification (Table 1).

\begin{tabular}{|l|l|l|l|l|}
\hline \multicolumn{1}{|c|}{ Genus } & Species & Accession & Specimen & $\begin{array}{c}\text { Indeterminate } \\
\text { accessions }\end{array}$ \\
\hline Burckella & 2 & 7 & 9 & 2 \\
\hline Chrysophyllum & 4 & 7 & 11 & 0 \\
\hline Diploknema & 1 & 3 & 5 & 0 \\
\hline Madhuca & 4 & 9 & 11 & 1 \\
\hline Manilkara & 4 & 17 & 10 & 0 \\
\hline Mimusops & 1 & 8 & 58 & 0 \\
\hline Palaquium & 11 & 52 & 3 & 18 \\
\hline Payena & 2 & 2 & 12 & 0 \\
\hline Planchonella & 3 & 11 & 39 & 0 \\
\hline Pouteria & 7 & 28 & 3 & 4 \\
\hline Sideroxylon & 1 & 1 & 9 & 0 \\
\hline Synsepalum & 1 & 6 & 11 & 31 \\
\hline Indeterminate & 0 & 61 & 207 & 0 \\
\hline Total & & 157 & 26 \\
\hline
\end{tabular}

Table 1 Review of Sapotaceae collection of Bogor Botanic Gardens (June 2016). 
Of the 41 named species of Sapotaceae cultivated in the garden 29 are native to Indonesia, representing just under $20 \%$ of Sapotaceae species currently recorded from Indonesia (Table 2). The non-native species cultivated were obtained from seed exchange programmes and donations from Peninsular Malaysia, Brazil, Central America, Philippines, tropical Africa, Cuba, Sri Lanka, India, Australia, tropical America, Italy, England and the USA.

\section{HERITAGE TREES AND CONDITION SURVEY}

The oldest specimen of a Sapotaceae tree that can still be found in the Garden is a Mimusops elengi var. parvifolia (R.Br.) H.J.Lam that was planted in 1823 and is originally from Java (Table 3). It is possible that other trees were planted before 1823 (30 collection numbers do not have complete collection or planting records or could be naturally occurring in the grounds of the Garden). Detailed investigation of old documents is needed to confirm the origin of these collections.

Important species originally recorded from the Garden but now dead include the tree from which the type of Palaquium rioense H.J.Lam was made and the oldest tree of Palaquium gutta (IV.B.29a). It has been suggested that this could be the parent of the $P$. gutta trees planted in the Cipetir gutta-percha plantation in Sukabumi, West Java, as before the plantation was established in 1885 the area was an experimental station operated by Bogor Botanic Gardens (about 19 years after the oldest $P$. gutta had been planted in the Garden).

Many heritage trees such as Payena leerii, Planchonella petaloides, Palaquium amboinense (IV.B.39) and Madhuca macrophylla (planted in 1931) are in good condition and flower and fruit almost every year. However, several are showing serious signs of age and are obviously coming to the end of their lives. The 193-year-old Mimusops elengi is still growing although the trunk leans and is now in need of support, and it has never set flower unlike younger trees of the same species. The trunk of the 157-year-old Palaquium ottolanderi, the only specimen of this species in the Garden, has obvious signs of decay caused by termites and again never flowers or sets fruit; and the 99-year-old Burckella macropoda (VII.E.37a) is susceptible to crown rot as the top has been split by strong winds.

\section{PURWODADI BOTANIC GARDEN, CIBODAS BOTANIC GARDEN AND BALI BOTANIC GARDEN}

Sapotaceae are also grown in the three other national botanic gardens operated by LIPI. As Sapotaceae are largely found in lowland forest it is not surprising that the lowland gardens contain more species with Bogor Botanic Gardens holding 41 named species and Purwodadi Botanic Garden 17, compared to the montane gardens with Cibodas Botanic Garden holding two and Bali Botanic Garden holding six named species (Table 4). 


\begin{tabular}{|c|c|c|}
\hline $\begin{array}{l}\text { IUCN } \\
\text { threat }\end{array}$ & Species & Origin \\
\hline- & Burckella macropoda (K.Krause) H.J.Lam & Maluku; W Java \\
\hline- & Burckella obovata (Foster) Pierre & Maluku \\
\hline Low* & Chrysophyllum inornatum Mart. & S Sulawesi \\
\hline- & Diploknema oligomera H.J.Lam & Sumatra: Aceh \\
\hline $\mathrm{Cr}^{*}$ & Madhuca boerlageana (Burck) Baehni & Maluku \\
\hline- & Madhuca macrophylla (Hassk.) H.J.Lam & $\begin{array}{l}\text { Maluku; N Sulawesi; S Kalimantan; } \\
\text { W Java }\end{array}$ \\
\hline- & Madhuca malaccensis (Clarke) H.J.Lam & Sumatra: Jambi \\
\hline- & Manilkara fasciculata (Warb.) H.J.Lam & N Maluku; N Sulawesi; Papua \\
\hline- & Manilkara kauki (L.) Duby & Lesser Sunda \\
\hline- & Mimusops elengi $\mathrm{L}$. & Java; N Sulawesi \\
\hline- & Mimusops elengi L. var. parvifolia (R.Br.) H.J.Lam & $\begin{array}{l}\text { Sumatra: Riau; Java; N Sulawesi; } \\
\text { Maluku; Papua }\end{array}$ \\
\hline- & Palaquium amboinense Burck & Java; C Sulawesi; Maluku \\
\hline- & Palaquium clarkeanum King \& Gamble & $\begin{array}{l}\text { Sumatra: Aceh; E Kalimantan; S } \\
\text { Kalimantan }\end{array}$ \\
\hline- & Palaquium gutta (Hook.) Baill. & $\begin{array}{l}\text { Sumatra: Jambi; Kalimantan; N Maluku; } \\
\text { Papua }\end{array}$ \\
\hline- & Palaquium obovatum (Griff.) Engl. & Java; SE Sulawesi; Maluku \\
\hline- & Palaquium obtusifolium Burck & N Sulawesi; Papua \\
\hline- & Palaquium ottolanderi Koord. \& Valeton & Java \\
\hline- & Palaquium pierrei Burck & W Kalimantan \\
\hline \multirow[t]{2}{*}{-} & Palaquium pseudocalophyllum H.J.Lam & Maluku \\
\hline & Palaquium rostratum (Miq.) Burck & S Sumatra \\
\hline- & Palaquium sumatranum Burck & W Sumatra \\
\hline- & Payena acuminata (Blume) Pierre & Java \\
\hline- & Payena leerii (Teijsm. \& Binn.) Kurz & Sumatra: Riau \\
\hline- & Planchonella duclitan (Blanco) Bakh.f. & N Sumatra; Java; SE Sulawesi; Papua \\
\hline- & Planchonella petaloides H.J.Lam & E Kalimantan; Maluku \\
\hline- & Pouteria firma (Miq.) Baehni & Gorontalo; Papua \\
\hline Low* & Pouteria grandiflora (A.DC.) Baehni & Java; Kalimantan \\
\hline- & Pouteria macrantha (Merr.) Baehni & N Sulawesi; Papua \\
\hline- & Pouteria obovata (R.Br.) Baehni & S Sumatra \\
\hline
\end{tabular}

IUCN Threat as of July 2016: - no assessment; * threat needs updated.

Table 2 List of native Sapotaceae species of Bogor Botanic Gardens (June 2016). 


\begin{tabular}{|c|c|c|c|}
\hline $\begin{array}{l}\text { Garden } \\
\text { number }\end{array}$ & $\begin{array}{c}\text { Year } \\
\text { planted }\end{array}$ & Species & Origin \\
\hline IV.D.100 & 1823 & Mimusops elengi L. var. parvifolia (R. Br.) H.J. Lam & Java \\
\hline IV.B.29a & 1866 & Palaquium pierrei Burck & W Kalimantan \\
\hline IV.C.39 & 1866 & Palaquium gutta (Hook.) Baill. & Kalimantan \\
\hline IV.D.14 & 1869 & Palaquium ottolanderi Koord. \& Valeton & Java \\
\hline IV.B.19 & 1887 & Manilkara fasciculata (Warb.) H.J.Lam \& Maas Geest. & Papua \\
\hline IV.C.81 & 1893 & Burckella macropoda (K.Krause) H.J.Lam & Maluku \\
\hline XI.B.XIV. 157 & 1895 & Palaquium obtusifolium Burck & N Sulawesi \\
\hline V.C.36 & 1909 & Mimusops elengi L. var. parvifolia (R. Br.) H.J. Lam & Papua \\
\hline VII.E.37a & 1917 & Burckella macropoda (K.Krause) H.J.Lam & $\begin{array}{l}\text { Maluku: Kai } \\
\text { Islands }\end{array}$ \\
\hline IV.B.4 & 1922 & Palaquium sumatranum Burck & Sumatra \\
\hline IV.B.2 & 1922 & Pouteria grandiflora (A.DC.) Baehni & Belgium* \\
\hline IV.A.39 & 1923 & Pouteria gardneriana (A.DC.) Radlk. & England* \\
\hline IV.B.1a & $1924 * *$ & Payena leerii (Teijsm. \& Binn.) Kurz & Riau, Sumatra \\
\hline VIII.G.23a & 1926 & Manilkara zapota (L.) P.Royen & Guatemala \\
\hline IV.D.97, 97a & $1926 * *$ & Madhuca boerlageana (Burck) Baehni & Maluku \\
\hline IV.D.1 & $1927 * *$ & Palaquium gutta (Hook.) Baill. & Kalimantan \\
\hline IX.D.3a & 1929 & Planchonella petaloides H.J.Lam & Maluku \\
\hline
\end{tabular}

* seed exchange programme; ** year of first redetermination - unknown planting date.

Table 3 Old specimens of Sapotaceae in Bogor Botanic Gardens.

The total number of native species grown in these gardens represents about $4 \%$ of the total found in Malesia and it is envisaged that this will increase as expert identifications are undertaken on the unidentified specimens and as new collections are made. These botanic gardens are an excellent resource that can help facilitate ex situ conservation of species from both lowland and montane environments.

\section{REGIONAL BOTANIC GARDENS}

Public awareness and understanding of conservation and biodiversity in Indonesia have been increasing in recent years and in response the Indonesian government has adjusted its policy and programme development initiatives so that its research and conservation institutions can respond accordingly. One national programme initiated by Bogor Botanic Gardens is the development of new regional botanic gardens across Indonesia. Indonesia is a megadiverse country containing 47 different ecoregions 


\begin{tabular}{|c|c|c|}
\hline $\begin{array}{c}\text { Botanic Garden } \\
\text { (BG) }\end{array}$ & Species & Origin \\
\hline \multirow[t]{6}{*}{ Cibodas BG } & Diploknema sp. & W Kalimantan \\
\hline & Madhuca lancifolia (Burck) H.J.Lam & Jambi \\
\hline & Mimusops elengi $\mathrm{L}$. & Jambi \\
\hline & Palaquium sp. & Papua \\
\hline & Payena sp. & W Sumatra \\
\hline & Pouteria sp. & W Java \\
\hline \multirow[t]{27}{*}{ Purwodadi BG } & Burckella sp. & E Kalimantan; Maluku; N Sulawesi \\
\hline & Chrysophyllum lanceolatum A.DC. & C Sulawesi; Papua \\
\hline & Chrysophyllum roxburghii G.Don & E Java \\
\hline & Chrysophyllum sp. & E Java \\
\hline & Madhuca macrophylla (Hassk.) H.J.Lam & E Java; C Sulawesi \\
\hline & Madhuca sp. & Maluku \\
\hline & Manilkara kanosiensis H.J.Lam \& B.Meeuse & Maluku \\
\hline & Manilkara kauki (L.) Dubard & Malesia \\
\hline & Manilkara sp. & C Sulawesi \\
\hline & Mimusops elengi $\mathrm{L}$. & E Java; C Sulawesi; Maluku; Papua \\
\hline & Mimusops sp. & Maluku \\
\hline & Niemeyera sp. & C Kalimantan; S Kalimantan \\
\hline & Palaquium bataanense Merr. & C Sulawesi \\
\hline & Palaquium obtusifolium Burck & Maluku \\
\hline & Palaquium pseudocalophyllum H.J.Lam & Papua \\
\hline & Palaquium rostratum (Miq.) Burck & W Kalimantan \\
\hline & Palaquium sp. & $\begin{array}{l}\text { E Java; Kalimantan; Sulawesi; Maluku; } \\
\text { Papua }\end{array}$ \\
\hline & Payena acuminata (Blume) Pierre & Java; SE Sulawesi \\
\hline & Payena lucida A.DC. & E Kalimantan \\
\hline & Payena sp. & E Kalimantan; S Kalimantan \\
\hline & Planchonella duclitan (Blanco) Bakh.f. & E Java; Papua \\
\hline & Planchonella firma (Miq.) Dubard & N Sulawesi \\
\hline & Planchonella obovata (R.Br.) Pierre & $\begin{array}{l}\text { E Java; N Sulawesi; SE Sulawesi; Maluku; } \\
\text { E Nusa Tenggara }\end{array}$ \\
\hline & Planchonella sp. & SE Sulawesi \\
\hline & Pouteria doonsaf P.Royen & Maluku; E Nusa Tenggara \\
\hline & Pouteria maclayana (F.Muell.) Baehni & E Java \\
\hline & Pouteria sp. & $\begin{array}{l}\text { Java; Sumatra; Kalimantan; Sulawesi; } \\
\text { Maluku; Papua }\end{array}$ \\
\hline \multirow[t]{9}{*}{ Bali BG } & Chrysophyllum sp. & Bali; E Nusa Tenggara \\
\hline & Manilkara kauki (L.) Dubard & Bali \\
\hline & Mimusops elengi $\mathrm{L}$. & Bali \\
\hline & Palaquium gutta (Hook.) Baill. & Bali \\
\hline & Palaquium obovatum (Griff.) Engl. & S Sulawesi; SE Sulawesi \\
\hline & Palaquium sp. & Bali; E Nusa Tenggara; SE Sulawesi \\
\hline & Payena leerii (Teijsm. \& Binn.) Kurz & Sumatra \\
\hline & Planchonella duclitan (Blanco) Bakh.f. & Bali \\
\hline & Planchonella sp. & Nusa Tenggara; S Sulawesi; SE Sulawesi \\
\hline
\end{tabular}

Table 4 Review of native Sapotaceae collections of the affiliated botanic gardens. 
(Kartawinata, 2013; Olson et al., 2001; Wikramanayake et al., 2002). The regional botanic garden initiative aims to set up gardens in each of these ecoregions to develop in situ and ex situ conservation initiatives for local floras. It is expected that these new botanic gardens will be able to deliver more effective ex situ conservation of local floras due to their proximity to local ecosystems and climate patterns. It is also hoped that by encouraging local people, government, university and the private sector to get involved, these local networks will raise awareness of conservation issues and develop community education, cultivation and conservation programmes. The development of regional botanic gardens will also help improve local economies through increased tourism.

The first regional botanic garden was established in 1999 in Jambi, Sumatra. Since then a presidential decree has been issued (No. 93, 2011) to enshrine the legality of these new gardens and to provide guidance on botanic garden development with regard to delivering and accelerating the national programme. Linked to this, Bogor Botanic Gardens established a department of planning and monitoring to support ex situ conservation development areas. By late 2014, 23 regional botanic gardens covering 15 ecoregions in Indonesia had been established (Purnomo et al., 2015). These new gardens have so far brought into cultivation 39 threatened species, which is about $9.65 \%$ of the known total threatened species of Indonesia (Purnomo et al., 2015). By mid-July 2016, 30 regional botanic gardens had been established (Fig. 1).

A network has now been established among these gardens to collect and share collection data and information. Although many new gardens are still developing their infrastructure and focusing on collecting and the establishment of nurseries a review of the Sapotaceae collections in the regional botanic gardens shows that they hold several local species of Sapotaceae (Table 5). At the same time these gardens are helping accelerate the collecting of Sapotaceae across Indonesia. In the last decade, ten species have been brought into cultivation from the surrounding forest of Balikpapan Botanic Gardens in East Kalimantan and 13 from the area around Enrekang Botanic Gardens in South Sulawesi (two new lowland regional botanic gardens). This has made a significant contribution to the total number of native Sapotaceae currently in cultivation from Kalimantan and Sulawesi (Table 5).

\section{CULTIVATION AND CARE OF SAPOTACEAE}

The key activities of botanic gardens are maintaining the health of cultivated plants and undertaking their propagation. From the latest inventory of the Bogor Botanic Gardens nursery (February 2016) there are 11 specimens (seedlings) consisting of Palaquium spp., Palaquium gutta, Pouteria cainito, Madhuca sp., Manilkara sp., of Sapotaceae ready to be planted into the collection. Duplicate seedlings propagated in the nursery are used mainly as backups, as material for dissemination, for reintroduction and reclamation programmes, or for other conservation-related programmes. A survey of Sapotaceae material in the Garden's nursery for distribution in early 2016 identified 


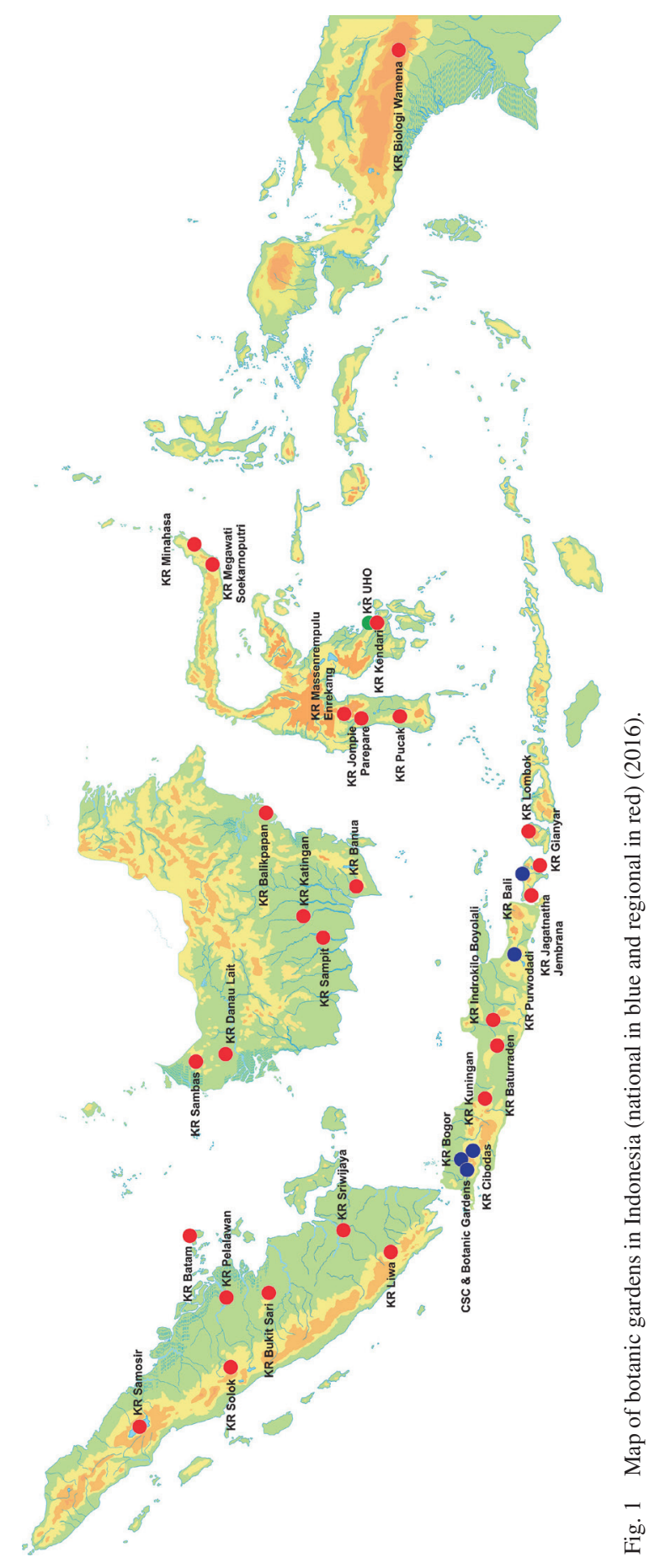




\begin{tabular}{|l|l|l|l|}
\hline \multicolumn{1}{|c|}{ Botanic garden (BG) } & \multicolumn{1}{c|}{ Location } & \multicolumn{1}{c|}{ Species } & No. of specimens \\
\hline Liwa BG & Lampung, Sumatra & 4 & 21 \\
\hline Kuningan BG & W Java & 7 & 31 \\
\hline Baturraden BG & C Java & 3 & 3 \\
\hline Lombok BG & W Nusa Tenggara & 3 & 3 \\
\hline Balikpapan BG & E Kalimantan & 10 & 69 \\
\hline Banua BG & S Kalimantan & 3 & 13 \\
\hline Katingan BG & C Kalimantan & 2 & 16 \\
\hline Enrekang BG & S Sulawesi & 13 & 105 \\
\hline Jompie BG & S Sulawesi & 3 & 10 \\
\hline
\end{tabular}

Table 5 Review of Sapotaceae collections held in regional botanic gardens.

268 seedlings of Manilkara zapota, Pouteria campechiana, Sideroxylon dulcificum, Manilkara sp. and Pouteria sp. available for conservation initiatives.

Most Sapotaceae propagation in the nursery is from seed. A skills shortage in cutting and grafting techniques in the Garden has meant that only a few Sapotaceae have been propagated from cuttings, layering or grafting. Likewise, the tissue culture of woody plants is not routinely undertaken as it has had high failure rates to date.

Many Sapotaceae seeds are recorded as recalcitrant (Baillonella toxisperma (Pangou et al., 2011), Pouteria multiflora (A. DC.) Eyma (Parrotta \& Francis, 1993), Madhuca indica J.F.Gmel. (Varghese et al., 2002)) or semi-recalcitrant (Manilkara zapota and Chrysophyllum cainito (Hong et al., 1998)). Truong et al. (2006) observed that Mimusops elengi seed viability can be reduced by desiccation during field collection by 8-12\%. At present the seed bank of Bogor Botanic Gardens has seed from 75 families, 246 genera and 435 species. Of these 17 are from Sapotaceae. These recalcitrant seeds are usually stored at $10-15^{\circ} \mathrm{C}$, in high seed-moisture conditions $(23-36 \%)$ for up to six months. In these conditions Pouteria campechiana seeds still had $45 \%$ moisture and 92\% viability after six weeks' storage (Widjaya, 2015).

\section{DISCUSSION}

Sapotaceae collections in Bogor Botanic Gardens go back to the 1800s when the Dutch brought many species back from expeditions around Indonesia. These collections resulted in the discovery of many new species and several of these collections are still growing in the Gardens today. However, many areas of Indonesia still remain unexplored, especially Sumatra and Kalimantan, and expeditions such as those organised by LIPI and the Royal Botanic Garden Edinburgh are bringing new material (including Sapotaceae) into cultivation for both display and ex situ conservation purposes. Expeditions like these 
are becoming increasingly important given the unprecedented rate of deforestation in Indonesia (Miettinen et al., 2011).

Of course in situ conservation is preferred and governments are playing their part with the designation of large areas of forest as national parks, nature reserves and protected forests (Widjaja et al., 2014) but botanic gardens also have an important role to play in ex situ conservation and this is recognised by the introduction of the regional botanic gardens initiative across Indonesia. Many of these gardens are at a very early stage but it is clear they are starting to have an impact as they have already brought into ex situ cultivation 39 threatened species (Purnomo et al., 2015). Bringing native species of Sapotaceae into cultivation will be a focus of research and conservation activities over the coming years. These collections are an important start but much more research will be needed to make sure that sufficient genetic diversity is captured in collections to maintain healthy populations of species in the future.

The placement of botanic gardens in Indonesia's 47 ecoregions will help bring a focus to the biodiversity of these areas and engage local stakeholders but it will also facilitate collection and conservation activities with gardens cultivating the important and threatened plants of each region. Key to the success of these gardens will be having the facilities and skills to cultivate and propagate collections. It has already been highlighted that many Sapotaceae seeds are recalcitrant and so it will be important to exchange knowledge and skills with other projects such as the Millennium Seed Bank of Kew Gardens in order to address this issue. Likewise, knowledge exchange and capacity building are required regarding cutting and grafting techniques and tissue culture of woody plants so that survival rates of trees being propagated in botanic gardens can be increased.

It has been highlighted that many early collections in Bogor Botanic Gardens had little associated data linked to them (locality, habitat, altitude and so on) and this has limited their scientific use. It is critical that new collections being introduced to botanic gardens in Indonesia have detailed collection information attached to them and that this data is recorded in a systematic way and stored for long-term use. This data will be particularly important in species identification and assessment of threat.

Of the 157 Sapotaceae accessions in Bogor Botanic Gardens 57\% have been identified to species, $35 \%$ to genus and $8 \%$ to family. The relatively high number of plants not yet identified to species underlines the need for experts to engage with and help identify cultivated material but also reflects some of the problems related to identifying living material of tropical trees which flower and fruit very infrequently, thus denying the expert the material needed to provide an accurate identification. It is in this regard that botanic gardens can play an important role in Sapotaceae research. Tropical trees in cultivation provide relatively easy and frequent access for researchers so that when they do eventually come into flower and fruit, observations and herbarium collections can be made. In Bogor Botanic Gardens the cultivated plant herbarium (KRB) can be used to store this valuable material and provides a great research resource for identification and conservation activities. Living collections also open up many different 
research opportunities such as the study of floral development, pollination biology or phenology investigations.

It has been estimated that the four national botanic gardens of LIPI can only conserve about $24 \%$ of the $30-40 \%$ of species currently assessed as threatened in Indonesia (Purnomo et al., 2015). This is in part due to the limited space available and the different ecosystems needed for different species to thrive. Of the 41 species of Sapotaceae currently cultivated in Bogor Botanic Gardens 29 are native to Indonesia, representing just under $20 \%$ of Sapotaceae species currently recorded from Indonesia. Of these only three have had a global threat assessment made of which two are considered as low risk and one, Madhuca boerlageana, as Critically Endangered.

Given the limitations placed on botanic gardens it is important that the species in cultivation are those which are most under threat. However, prioritisation of Sapotaceae species collection and cultivation is problematic given that very few assessments of threat have been made to date. It is therefore a matter of urgency that new and updated assessments of Sapotaceae are undertaken. The establishment of an Indonesian Plant Red List Authority by the Research Centre for Biology of the Indonesian Institute of Sciences is a major step forward as are the efforts of the Sapotaceae taxonomic community in pooling expertise across the world to deliver global assessments of all Sapotaceae. Better linkage of data held in herbaria with data and field observations made of natural habitats while collecting material for ex situ collections in botanic gardens will also contribute greatly to the production of IUCN assessments. As more threat assessments are undertaken the number of Sapotaceae species identified as under threat is sure to increase. It is essential that threat assessment data is widely available so that policy makers can incorporate it into National Biodiversity Strategy and Action Plans (NBSAPs) and forest managers and conservation groups can make sensible conservation decisions. Indonesia, as a country with very high biodiversity and levels of endemism of Sapotaceae, has a crucial role to play in conserving the Sapotaceae of Indonesia and the Malesian region.

\section{CONCLUSION}

The four national botanic gardens of LIPI together with the new Indonesian regional botanic gardens can make a significant contribution to supporting plant (including Sapotaceae) conservation. As deforestation and land alteration continue at an alarming rate it is increasingly important to document, describe and assess the threat to the plant diversity of Indonesia so that activities can be prioritised. In doing this botanic gardens will contribute to Target 2 of the GSPC (2011-2020): "an assessment of the conservation status of all known plant species, as far as possible, to guide conservation action" and Target 8: "at least $75 \%$ of threatened plants in ex situ collection".

The regional botanic garden programme is a significant step in contributing to the conservation and research of Indonesia's plant diversity as well as education, tourism and the local economy. The success of the programme relies on the strong commitment of central and local government, good garden management and engagement by local 
communities. The establishment by Bogor Botanic Gardens of the department for planning and monitoring to build networks, encourage partnerships, provide guidance, facilitate capacity building programmes and link funding sources is of paramount importance if regional botanic gardens are to become key actors for plant conservation in Indonesia.

\section{ACKNOWLEDGEMENTS}

We thank the Director of the Centre for Plant Conservation Botanic Gardens - LIPI and all staff in the Ex situ Conservation Division for providing data and information. We are grateful also to M. Bima Atmaja (Bali Botanic Gardens), Ilham K. Abywijaya (Purwodadi Botanic Gardens), M. Muhaimin (Cibodas Botanic Gardens) and the management teams of the regional botanic gardens in helping us obtain up-to-date information.

\section{REFERENCES}

BOER, E. \& ELLA, A.B. (eds) (2001). Plants Producing Exudates. Plant Resources of SouthEast Asia, No. 18. PROSEA, Bogor.

GOVAERTS, R., FRODIN, D.G. \& PENNINGTON, T.D. (2001). World Checklist and Bibliography of Sapotaceae. Royal Botanic Gardens, Kew.

HONG, T.D., LININGTON, S. \& ELLIS, R.H. (1998). Compendium of Information on Seed Storage Behaviour, Volume 2 (I-Z). Royal Botanic Gardens, Kew.

IUCN (2001). The IUCN Red List of Threatened Species. Available online: www.iucnredlist.org (accessed 18 February 2017).

KARTAWINATA, K. (2013). Diversitas Ekosistem Alami Indonesia. Ungkapan singkat dengan sajian foto dan gambar. LIPI Press \& Yayasan Obor, Jakarta.

LEMMENS, R.H.M.J., SOERIANEGARA, I. \& WONG, W.C. (eds) (1995). Plant Resources of South-East Asia, No. 5(2). Timber Trees: Minor Commercial Timbers. Backhuys Publishers, Leiden.

MIETTINEN, J., SHI, C. \& LIEW, S.C. (2011). Deforestation rates in insular Southeast Asia between 2000 and 2010. Global Change Biology, 17: e2261-e2270.

NG, F.S.P. (1972). Sapotaceae. In: WHITMORE, T.C. (ed.) Tree Flora of Malaya vol. 1. Longman Malaysia, Kuala Lumpur, p. 473.

OLSON, D.M., DINERSTEIN, E., WIKRAMANAYAKE, E.D., BURGESS, N.D., POWELL, G.V.N., UNDERWOOD, E.C., D'AMICO, J.A., ITOUA, I., STRAND, H.E., MORRISON, J.C., LOUCKS, C.J., ALLNUTT, T.F., RICKETTS, T.H., KURA, Y., LAMOREUX, J.F., WETTENGEL, W.W., HEDAO, P. \& KASSEM, K.R. (2001). Terrestrial ecoregions of the world: a new map of life on Earth. BioScience, 51(11): 933-938.

PANGOU, S.V., DE ZOYSA, N., MAURY, G., MASANGA, A. \& PANGOU-YOKA, C.M. (2011). Seed storage behaviour of some indigenous valued tropical tree species from Congo (Africa). International Research Journal of Agricultural Science and Soil Science, 1(8): 307-313. 
PARROTTA, J.A. \& FRANCIS, J.K. (1993). Pouteria multiflora (A.DC.) Eyma. Jacana, Bullytree. Sapotaceae. Sapodilla family. Technical report, USDA Forest Service, International Institute of Tropical Forestry. Available online: https://www.fs.usda.gov/treesearch/ pubs/30354 (accessed 29 January 2018).

PENNINGTON, T.D. (1991). The Genera of Sapotaceae. Royal Botanic Gardens, Kew.

PURNOMO, D.W., MAGANDHI, M., KUSWANTORO, F., RISNA, R.A. \& WITONO, J.R. (2015). Pengelolaan Koleksi Kebun Raya dalam Kerangka Strategi Konservasi Tumbuhan Indonesia. Buletin Kebun Raya, 18(2): 111-124.

RAKOW, D.A. \& LEE, S.A. (2011). Public Garden Management. John Wiley \& Sons, Hoboken, NJ.

SOERIANEGARA, I. \& LEMMENS, R.H.M.J. (eds) (1994). Plant Resources of South-East Asia, No. 5(1). Timber Trees: Major Commercial Timbers. Backhuys Publishers, Leiden.

SOSEF, M.S.M., WONG, L.T. \& PRAWIROHATMODJO, S. (eds) (1998). Plant Resources of South-East Asia, No. 5(3). Timber Trees: Lesser-known Timbers. Backhuys Publishers, Leiden.

TRUONG, M.H., TRAN, D.H., NGUYEN, T.H., HAI, H.H., TUNG, T.D., LE-TAM, V.T., NGOC-TAM, B. \& ELLIS, R.H. (2006). Seed development, maturation and storage behavior of Mimusops elengi L. New Forests, 32: 9-19.

VARGHESE, B., NAITHANI, R., DULLOO, M.E. \& NAITHANI, S.C. (2002). Seed storage behaviour in Madhuca indica J.F. Gmel. Seed Science \& Technology, 30: 107-117.

WIDJAJA, E.A., RAHAYUNINGSIH, Y., RAHAJOE, J.S., UBAIDILLAH, R., MARYANTO, I., WALUJO, E.B. \& SEMIADI, G. (2014). Kekinian Keanekaragaman Hayati Indonesia 2014. LIPI Press, Jakarta.

WIDJAYA, A.H. (2015). Viabilitas Benih Campolay (Pouteria campechiana (Kunth) Baehni) Pada Berbagai Bobot Dan Lama Penyimpanan Benih. Unpublished undergraduate thesis, Pakuan University, Bogor.

WIKRAMANAYAKE, E., DINERSTEIN, E., LOUCKS, C.J. et al. (2002). Terrestrial Ecoregions of the Indo-Pacific: A Conservation Assessment. Island Press, Washington, DC.

WILKIE, P. (2011). Towards an account of Sapotaceae for Flora Malesiana. Gardens' Bulletin Singapore 63(1 \& 2): 145-153. 